getrockneten Gewebe bzw. im Blutrückstand. Sie enthalten folglich kein Tritiumwasser. Eine Analyse des Blutkondensats wurde nicht vorgenommen. Statt dessen wurde die ${ }^{3} \mathrm{H}$-Aktivität im Körperwasser aus der spezifischen Aktivität im kondensierten Wasser der Atemluft berechnet. Die Berechnung geht von folgenden Annahmen aus: 1. Das Tritiumwasser in der Abluft des Käfigs stammt aus dem intermediären Stoffwechsel des Meerschweinchens. 2. Die spezifische Aktivität des Wassers, das im trockenen Käfig in den letzten Stunden vor der Tötung des Tieres entsteht, entspricht der spezifischen Aktivität des Körperwassers.

Der Anteil der injizierten Aktivität, der 3 Tage nach der Dextraninjektion im Körper wiedergefunden wurde, liegt zwischen $76 \%$ bei der höhermolekularen und $13 \%$ bei der niedermolekularen Fraktion. Diese hohe Abhängigkeit vom Molekulargewicht des injizierten Dextrans wird allerdings vorwiegend durch die Verweildauer im Blut bestimmt (s. Abb. 2), während die Gesamt- ${ }^{3} \mathrm{H}$-Aktivität der in den Geweben nachgewiesenen ${ }^{3} \mathrm{H}$-Aktivitäten mit Ausnahme der kleinstmolekularen Fraktion (Fraktion V) sich weitgehend angleicht. Die molekulargewichtsabhängige Retention in einzelnen Organen, z. B. in der Milz (s. Abb. 5) ist für die Bilanz ohne Bedeutung. Abschnitt 4 der Tabelle 3 bringt den Anteil der injizierten ${ }^{3} \mathrm{H}$-Aktivitäten, der im Urin, im Kot und in der Atemluft wiedergefunden wurde. Der Ablauf dieser Ausscheidungen wurde in den Abbildungen 3 und 4 beschrieben und bereits oben diskutiert. Innerhalb von 3 Tagen nach der Dextraninjektion wurden zwischen $20 \%$ und $86 \%$ ausgeschieden. Diese Werte entsprechen im umgekehrten Sinne den Blutwerten, so daß die Bilanzen der einzelnen Versuche nahe $100 \%$ liegen. Nach den vorliegenden Ergebnissen ist die molekulargewichtsabhängige Verweildauer von Dextran im Blut deshalb vorwiegend eine Funktion der Ausscheidung. Retention oder Metabolisierung in den Geweben sind in dieser Hinsicht von untergeordneter Bedeutung.

Wir danken der Knoll AG, Chemische Fabriken, Lud wigshafen a. Rh., für die großzügige Unterstützung dieser Arbeiten, Frau Dr. K. Granath, Pharmacia AB, Uppsala, für die Ausführung der Molekulargewichtsverteilungsmessungen, Herrn Dr. J. KLEIN für die Durchführung der präparativen Fraktionierung und Herrn Mechanikermeister AlbERT SCHALlweg für Konstruktion und Anfertigung des Stoffwechselkäfigs.

\title{
Literatur
}

1. Grotte, G., R. C. Knutson und J. L. Bollmann, J. Laborat. Clin. Med. S. Louis 38, 577 (1951). - 2. Arturson, G. und G. Wallenius, Scand. J. Clin. Laborat. Inivest. 1, 76 (1964). - 3. Arturson, G. und G. Wallenius, Scand. J. Clin. Laborat. Invest. 1, 81 (1964). - 4. Arturson, G., K. Granath und G. Grotre, Arch. Dis. Childh. London 41, 168 (1966). - 5. SchwartzkopfF, W., Verh. Dtsch. Ges. inn. Med. 70, 705 (1964). 6. Arturson, G. Scand. J. Clin. Laborat. Invest. 17, Suppl. 86, 69 (1965). - 7. Hellmann, Prel. Report on the Metabolism of C-14 Labelled Dextran and PVC, Report to National Research Council, October 1951. - 8. Aberg, B., W. L. Bloom und E. Hansson, Acta physiol. Scand. 52, 188 (1961). - 9. Terry, R., Ch. L. Yuile; A. Golodetz, C. E. Phillips und R. R. Whrte, J.
Laborat. Clin. Med. S. Louis 42, 6 (1953). 10. Gray, I. P. K. Sitery und E. J. Pulaski, Proc. Soc. exper. Biol Med. 77, 626 (1951). - 11. Gray, I., Amer. J. Physiol. 174 462 (1953). - 12. Rosenfeld, E. L. und A. S. Satenko, Clin. chimica Acta Amsterdam 10, 223 (1964) - - 13. Ebert, K. H. und M. Brosche, Biopolymers 5, 423 (1967). - 14. EbERT, K. H., G. Rupprecht und G. Schenk, Z. Naturforsch. 18b, 442 (1963). 15. Granath, K. A. und B. E. Kvist, J. Chromatog. 28, 69 (1967). - 16. Klein, J. und E. KillmanN, Makromol. Chem. 96, 193 (1966). - 17. Kalberer, F. und J. Rutschmann, Helv. chim. Acta 44, 1957 (1961). - 18. ChytiL, F, L. Lacko und O. STĚRBA, Blut XII, 310 (1966).

Doz. Dr. K. Ebert 8000 München 2 Arcisstr. 21

\section{A New Method for the Determination of Serum Nucleotidase}

\author{
By J.-P. Persijn, W. van Der Stik, K. KRAmer and C. A. De Ruijter \\ From the Department of Clinical Chemistry (Head, Dr. J.-P. Persijn), Netherlands Cancer Institute, Amsterdam, and the \\ Department of Clinical Chemistry, State University Hospital, (Head, Drs. W. van der Slik), Leiden, The Netherlands.
}

(Eingegangen am 8. Mai 1968)

A new method for the determination of serum nucleotidase (EC 3.1.3.5) is described; its accuray and reproducibility have been investigated. For determinations in serum the coefficients of variation were $2.5-3.5 \%$.

The serum $5 \mathrm{~N}$ activity is measured by the amount of $\mathrm{NH}_{3}$ liberated from adenosine after incubation with the enzyme adenosine deaminase (EC 3.5.4.2).

Eine neue Methode für die Bestimmung der Serum-Nucleotidase (EC 3.1.3.5) wird beschrieben, ihre Genauigkeit und Reproduzierbarkeit untersucht. Für die Bestimmung im Serum betragen die Variationskoeffizienten 2,5-3,5\%.

Die Aktivität des Serums gegenüber AMP wird nach Inkubation mit Adenosindesaminase (EC 3.5.4.2) bestimmt, gemessen wird das dabei freigesetzte Ammoniak. 
Serum activity towards adenosine- 5 -phosphate at pH 7.5 - which will be described for convenience as serum $5^{\prime}$-nucleotidase $(5 \mathrm{~N})$ - has been noted as being markedly enhanced in cases of malignant intrahepatic obstruction and some other diseases of the hepatobiliary system (1-7).

The determination of the activity of this enzyme in serum is of still more interest since in cases of several bone diseases involving osteoblastic activity, the level of $5 \mathrm{~N}^{1}$ ) is not affected, whereas the level of alkaline phosphatase (AP) increases in both liver and bone diseases $(1,2,4,5,7)$.

The assay of serum $5 \mathrm{~N}$ activity is commonly achieved by measuring the amount of inorganic phosphorus liberated from adenosine-5'-monophosphate according to Fiske and Subbarow (8) after a certain incubation period. This procedure involves therefore the determination of endogeneous inorganic $P$ to be subtracted from the amount of total $\mathrm{P}$ as found after the incubation. In normal and slightly pathological cases, however, the serum activity towards AMP is of such low degree that in fact only slightly different amounts of phosphorus have to be subtracted from each other. Because of this limitation of the sensitivity it was decided to base the assay of $5 \mathrm{~N}$ on the amount of adenosine liberated from the substrate. Adenosine can be quantitatively determined using the enzyme ADA which specifically converts adenosine according to the equation:

$$
\text { Adenosine }+\mathrm{H}_{2} \mathrm{O} \longrightarrow \text { Inosine }+\mathrm{NH}_{3}
$$

KALCKAR (9) showed that the decrease in optical density at $265 \mathrm{~nm}$ resulting from the enzymic deamination is proportional to the adenosine concentration and that this type of reaction can be used for the determination of adenosine.

In 1960 SEGAL and BRENNER used this reaction in their study of $5^{\prime}$-nucleotidase activity in rat liver microsomes (10). After incubation of the microsomes in tris buffer containing AMP, the test mixture was deproteinized. Adenosine was determined (by decrease in absorbance at $265 \mathrm{~nm}$ ) according to KALCKAR and phosphate was determined according to FISkE and SUBBAROw. Both determinations served for the calculation of $5 \mathrm{~N}$ activity. The results agreed within 5\% with each other.

For practical reasons in the routine clinical chemical laboratory simple colorimetric reactions are to be preferred to measurements of change in optical density in the ultraviolet region such as at $265 \mathrm{~nm}$. We thought it useful to apply a sensitive colorimetric reaction for the enzymically liberated ammonia in the determination of adenosine. Thus the blue colour formed by ammonia and phenol in an alkaline oxidizing medium (indophenol reaction of BERTHELOT) was chosen.

It is the purpose of this paper to show that this reaction can be adapted to the assay for 5'-nucleotidase in serum.

1) The following abbreviations are used: $A D A=$ adenosine deaminase (EC 3.5.4.2); AP = alkaline phosphatase (EC 3.1.3.1); $5 \mathrm{~N}=$ activity towards $\mathrm{AMP} ; \mathrm{P}=$ inorganic phosphate $; \mathrm{PhP}=$ phenylphosphate; SGOT $=$ serum aspartate aminotransferase (EC 2.6.1.1).
In the method reported, serum, substrate (AMP) and excess of $\mathrm{ADA}$ are incubated together, after which the ammonia originating from the adenosine is determined photometrically. The present method for measuring $5 \mathrm{~N}$ activity is much easier to perform in practice and has a much higher sensitivity than the usual methods based on inorganic phosphorus determination.

\section{Methods}

\section{Reagents}

The $5 \mathrm{~N}$-ammonia method

1. Adenosine deaminase solution (ADA).

Dilute $0.2 \mathrm{ml}$ from stock suspension (Boehringer, $2 \mathrm{mg} / \mathrm{ml}$ in $\left.2.8 \mathrm{M}\left(\mathrm{NH}_{4}\right)_{2} \mathrm{SO}_{4}\right)$ to $15 \mathrm{ml}$ with phosphate buffer, $0.001 \mathrm{M}, \mathrm{pH} 6.0$. This diluted solution is dialyzed at $2^{\circ} \mathrm{C}$ overnight against phosphate buffer $0.001 \mathrm{M}, \mathrm{pH} 6.0$ to remove the ammonium salts. This solution is stable for two weeks at $4^{\circ} \mathrm{C}$.

\section{Buffer solution}

Dissolve $4.20 \mathrm{~g}$ sodium diethylbarbiturate (Veronal sodium) and $6.30 \mathrm{~g} \mathrm{MgSO}_{4} \cdot 7 \mathrm{H}_{2} \mathrm{O}$ (A. R. grade) in about $800 \mathrm{ml}$ water. Adjust the $\mathrm{pH}$ to 7.5 with $\mathrm{N} \mathrm{HCl}$ and dilute to $1000 \mathrm{~m} l$ with water. The solution can be used for a month if stored at $4^{\circ} \mathrm{C}$.

3. Buffer / ADA solution

Mix $150 \mathrm{~m} l$ buffer with $15 \mathrm{~m} l$ dialyzed ADA solution. This is stable for two weeks at $4^{0} \mathrm{C}$.

\section{Buffered substrate / ADA solution}

Dissolve $0.250 \mathrm{~g}$ adenosine- $5^{\prime}$-monophosphate in $100 \mathrm{~m} /$ buffer $/$ $\mathrm{ADA}$. This solution is prepared fresh before use.

5. Ethylendiaminetetra-acetic acid dipotassium salt (EDTA) Dissolve $5.6 \mathrm{~g}$ EDTA $\cdot 2 \mathrm{H}_{2} \mathrm{O}$ in water and dilute to $50 \mathrm{ml}$.

\section{Phenol colour reagent (concentrated)}

Dissolve $50.0 \mathrm{~g}$ phenol (A. R. grade) and $0.25 \mathrm{~g}$ disodiumpentacyanonitrosylferrate (A. R. grade) in water and dilute to $1 \mathrm{l}$. Stable at least two months if kept cool and in an amber bottle protected from light.

\section{Phenol colour reagent / EDTA solution}

Dilute 1 volume concentrated phenol colour reagent with 4 volumes water. To $100 \mathrm{~m} l$ solution is added $2 \mathrm{~m} l$ EDTA solution. This solution must be prepared fresh before use.

\section{Alkali-Hypochlorite reagent (concentrated)}

Dissolve $25.0 \mathrm{~g}$ Sodium hydroxide (A. R. grade) in $60 \mathrm{~m} l$ water. Add $72 \mathrm{ml}$ of a commercial Sodium hypochlorite solution containing $0.5 \mathrm{M}(5 \%) \mathrm{NaClO}$ and dilute to $1 l$. Care should be taken that the solution is at least $0.07 \mathrm{~N}$ to $\mathrm{J}_{2}$ since otherwise erroneous results will be obtained. Stable at least two months if kept cool and in an amber bottle protected from light.

\section{Alkali-Hypochlorite reagent (diluted)}

Dilute 1 volume concentrated alkali-hypochlorite reagent with 4 volumes water. This solution must be prepared fresh before use.

10. Adenosine stock standard (3.7 mMol per liter)

Dissolve $100 \mathrm{mg}$ adenosine (Boehringer) in saturated benzoic acid and dilute to $100 \mathrm{~m} l$. The standard is stable for some months in the refrigerator.

\section{Adenosine working standards}

a) Dilute $2.0 \mathrm{~m} /$ adenosine stock standard to $10.0 \mathrm{~m} /$ with water. b) Dilute $5.0 \mathrm{~m} l$ stock standard to $10.0 \mathrm{~m} l$ with water.

\section{Procedure}

\section{The $5 \mathrm{~N}$ Ammonia method}

The detailed standard procedure is as follows: to a series of test tubes, placed in a waterbath at $37^{\circ} \mathrm{C}$ different amounts are added as outlined in table 1 . 
Tab. 1

Standard procedure

\begin{tabular}{lcccc}
\hline & $\begin{array}{c}\text { buffer/ADA } \\
(\mathrm{ml})\end{array}$ & $\begin{array}{c}\text { buffer/ } \\
\text { Substr/ADA } \\
(\mathrm{ml})\end{array}$ & $\begin{array}{c}\text { standard } \\
(\mathrm{ml})\end{array}$ & $\begin{array}{c}\text { serum } \\
(\mathrm{ml})\end{array}$ \\
\hline $\begin{array}{c}\text { Unknown } \\
\text { Standards }\end{array}$ & 1.0 & 1.0 & - & 0.1 \\
$\begin{array}{c}\text { Unknown } \\
\text { blank }\end{array}$ & 1.0 & - & - & 0.1 \\
$\begin{array}{c}\text { Standard } \\
\text { blanks }\end{array}$ & 1.0 & - & 0.1 & - \\
\hline
\end{tabular}

Mix thoroughly and stopper. After $60 \mathrm{~min}$. incubation $5 \mathrm{ml}$ of diluted phenol colour reagent (containing EDTA) are added to each tube. Immediately after mixing, $5 \mathrm{~m} l$ of the diluted alkalihypochlorite reagent are added. The time between these additions should be kept as short as possible. The tubes are stoppered again and left in the waterbath for a period of $30 \mathrm{~min}$.

Readings of the absorbances of the unknown $\left(A_{\mathbf{x}}\right)$, standard $\left(A_{\mathbf{s}}\right)$ are made against their corresponding blanks at $625 \mathrm{~nm}$ using $1 \mathrm{~cm}$ cells.

Modifications of the procedure are described under Comments on the Procedure.

\section{Controls}

\section{Removal of anımonia during dialysis}

To a tube containing $0.1 \mathrm{~m} /$ of the dialyzed ADA solution are added succesively $1 \mathrm{~m} /$ buffer, $5 \mathrm{~m} /$ phenol-EDTA reagent and $5 \mathrm{~m} l$ of diluted alkali-hypochlorite solution. The tube is stoppered and left to stand at $37^{\circ} \mathrm{C}$ for $30 \mathrm{~min}$. Absorbances are read at $625 \mathrm{~nm}$ against a blank which contains $0.1 \mathrm{~m} l$ water instead of ADA. The absorbance values generally equal approximately 0.090 if only 9 hours dialysis has taken place and are about zero if dialysis has been performed overnight.

\section{Activity' of dialyzed $A D A$}

To a tube containing $0.1 \mathrm{ml}$ of the dialyzed ADA is added $0.2 \mathrm{ml}$ adenosine stock solution and $1 \mathrm{~m} /$ buffer. After stoppering and standing at $37^{\circ} \mathrm{C}$ for $2 \mathrm{~min}$., the reagents for ammonia are added as described above. The absorbance is read at $625 \mathrm{~nm}$ against a blank which contains water instead of adenosine solution and should not be below 1.100 .

\section{Calculation}

$\frac{A_{\mathbf{x}}}{A_{\mathbf{s}}} \cdot C_{\mathbf{s}} \cdot 16,7=$ International milli Units per $\mathrm{m} /$ serum.

$\mathrm{C}_{\mathrm{s}}=$ concentration standard in $\mu \mathrm{Mol}$ per $\mathrm{ml}$.

The factor $16.7=0.1 \cdot \frac{10000}{60}$ is derived from:

sample volume: $0.1 \mathrm{ml}$

IU is expressed per liter serum: 10000

IU is expressed per minute: 60 .

The $5 \mathrm{~N}$-phosphate method

The procedure of Hepper and Hirmoe (11) was followed with some modifications:

1. The reaction mixture $(3.2 \mathrm{~m} l)$, contained $3 \mathrm{~m} l$ Veronal buffer (composition described under reagents), and $0.2 \mathrm{~m} l$ serum.

2. The incubation time was $30 \mathrm{~min}$.

3. The reducing agent (ammonium ferrous sulphate) for the determination of inorganic phosphorus was used.

The calculation of $5 \mathrm{~N}$ activity was based on standards of mono basic potassium phosphate, which had undergone the same treatment. Activity is expressed in International milli Units per $\mathrm{m} l$ serum.

Apparatus

All the readings were made with a Gilford 300 microsample spectrophotometer showing linearity in optical density at $625 \mathrm{~nm}$ up to 2.300 .
Comments on the Procedure

Source of $A D A$

Comparative studies of ADA from different mammalian species have shown a wide variety of properties. For our procedure, in which to save time, substrate and $A D A$ are combined during the incubation at $\mathrm{pH} 7.4$, it was decided to use ADA from calf intestine for three reasons.

First, as has been shown by CHilson and Fisher (12), ADA has optimal activity at $\mathrm{pH} 7$, whereas, for example, ADA from chicken duodena has a minimum activity at this $\mathrm{pH}$.

Secondly ADA from calf has no measurable activity towards AMP. Thirdly, as has been published by BrADY (13), the calf enzyme is not affected by a variety of commonly used inhibitory compounds such as Veronal (which is used as buffer), fluoride, magnesium ions (which are used as activator for $5 \mathrm{~N}$ ), phosphate or manganese ions, etc.

A drawback of commercially available suspensions of calf ADA is their high content of ammonium salts which act as a stabilisor. The removal of these salts has not proved to be difficult in practice.

\section{Activity of the dialyzed $A D A$}

The activity of ADA was about $25 \%$ lower than that of undialyzed ADA. The activities were determined according to KALCKAR (9). Later it was realised that the activity could also be determined by estimating the amount of ammonia liberated per minute from adenosine. As a control the complete conversion of an amount of adenosine corresponding to a $5 \mathrm{~N}$ activity of about $120 \mathrm{mU} / \mathrm{m} l$ within $2 \mathrm{~min}$. was considered to fullfil the requirements of the test.

The indophenol blue reaction: addition of EDT $A$ to the phenol reagent The blue colour of indophenol formed by ammonium hypochlorite and phenol in an alkaline medium was first reported by BERTHELOT (14). Since the report of Berthelot numerous varieties of this same basic reaction have been described. After several experiments the procedure as described under "Methods" was chosen. This is very similar to the version introduced by CHANEY and MARBACH (15). An important difference is the addition of EDTA to the phenol reagent to chelate $\mathrm{Mg}$ ions, which are otherwise precipitated by the alkaline hypochlorite reagent. For reasons of efficiency, the addition of EDTA, which was found to have no influence on the accuracy of the ammonia determination, was preferred to centrifigation of the $\mathrm{Mg}$ precipitate.

The appearance of precipitate could be avoided if the actual concentration of $\mathrm{Mg}$ in the buffer substrate was reduced from $25.5 \mu \mathrm{Mol} / \mathrm{m} l$ to $2 \mu \mathrm{Mol} / \mathrm{ml}$.

From figure 1 it is, however, evident that such a reduction considerably lowers the measurable activity to AMP.

\section{Results}

Figure 2 illustrates a calibration curve obtained with different dilutions of adenosine stock solution. The plot is linear to at least $0.8 \mu \mathrm{Mol}$ adenosine in the final test volume, corresponding to a serum $5 \mathrm{~N}$ activity of $133 \mathrm{mU} / \mathrm{m} l$ (normal range $4-14 \mathrm{mU} / \mathrm{ml}$ ). The time course of $5 \mathrm{~N}$ reactions in the case of serums with different levels of enzyme activity is given in figure 3, showing linearity with incubation time. Curve a, concerns a serum with a normal $5 \mathrm{~N}$ value and is therefore a good illustration of the sensivity of the method.

Serum exhibits ADA activity with a $\mathrm{pH}$ optimum of 7.2 (16). The assay on the serum represented in figurc 3 , curve $b$, was repeated while omitting the addition of dialyzed ADA to the buffered substrate solution (fig. 4). It will be noted that serum ADA ist not capable of converting the adenosine formed to ammonia at a sufficient rate under the conditions of the test. The serum activity 


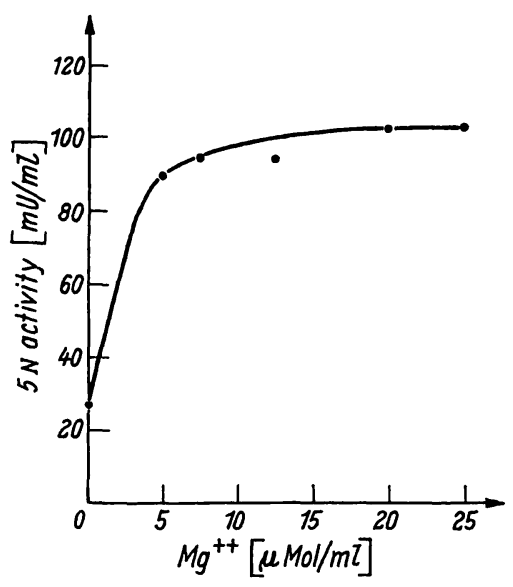

Fig. 1

Effect of $\mathrm{Mg}^{++}$(final concentrations) on the $5 \mathrm{~N}$ activity, measured by the $\mathrm{PO}$, method

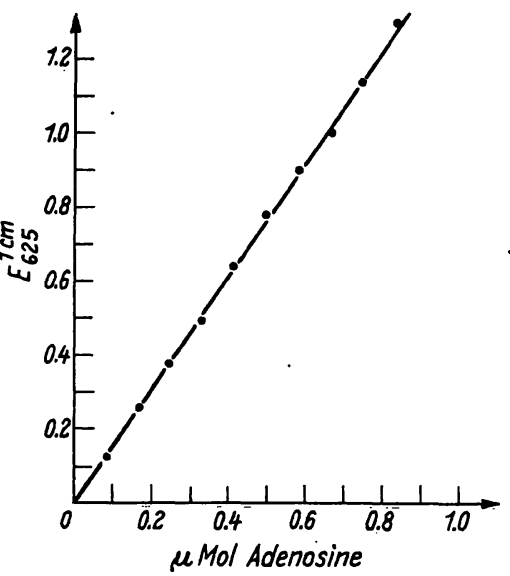

Fig. 2

Calibration curve

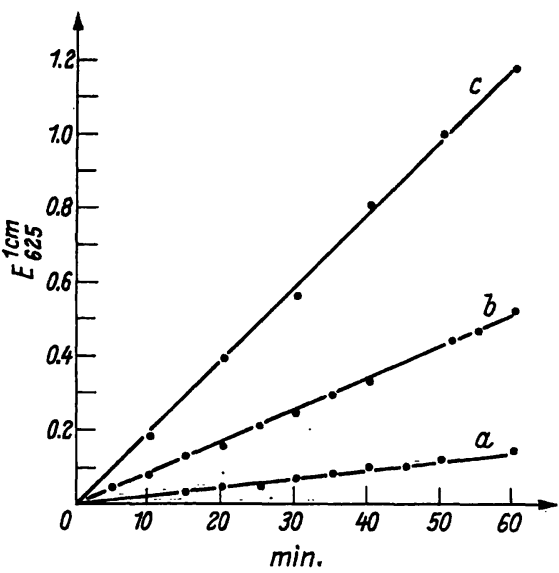

Fig. 3

Time course of $5 \mathrm{~N}$ activity a) normal level, b) and c) elevated levels as measured by the indophenol blue reaction

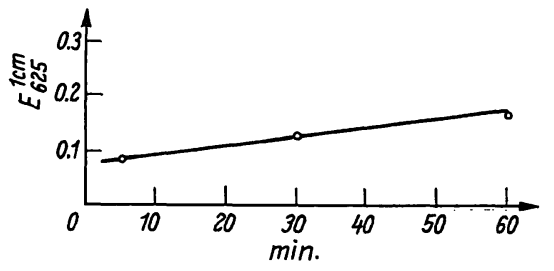

Fig. 4

Time course of $5 \mathrm{~N}$ activity when calf ADA is absent from the incubation mixture

Measured by the indophenol blue reaction. The serum sample is identical with the sample represented in figure 3, curve b)

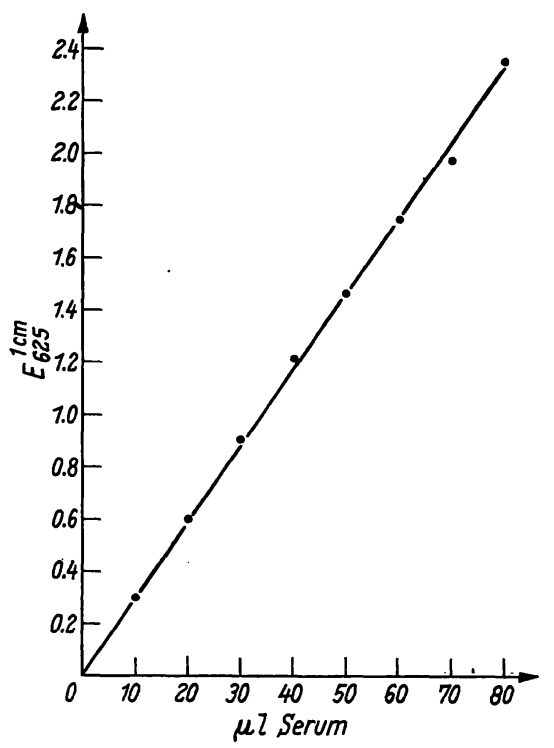

Fig. 5

Relation of enzyme concentration to enzyme activity as measured by the indophenol blue reaction

of $5 \mathrm{~N}$ is directly proportional to the amount of serum assayed (fig. 5).

The agreement of the results of assays with the ammonia method and the phosphate method was good, but the ammonia method proved to be far more sensitive. In table 2 the coefficients of variation (C. V.) of different series of serums analysed in duplicate are shown.
Tab. 2

Coefficient of variations (C. V.) for different series of serums (normal values $4-14 \mathrm{mU} / \mathrm{ml}$ )

\begin{tabular}{ccc}
\hline $\begin{array}{c}\text { Range } \\
(\mathrm{mU} / \mathrm{ml} \text { serum }\end{array}$ & $\begin{array}{c}\text { C. V. } \\
\%\end{array}$ & $\begin{array}{c}\text { number of } \\
\text { duplicates }\end{array}$ \\
\hline $0-20$ & \pm 3.5 & 34 \\
$20-40$ & \pm 2.5 & 14 \\
$40-60$ & \pm 2.7 & 15 \\
$60-80$ & \pm 3.4 & 9 \\
\hline
\end{tabular}

The coefficients of variations were calculated from the standard deviation S by the formule C. V. $=\frac{100 \mathrm{~S}}{\overline{\overline{\mathrm{x}}}}$ (17).

Results of recovery experiments using normal and pathological serums to which adenosine had been added appear in table 3 . For these experiments a serum was diluted twofold with an adenosine solution in physiological saline and twenty $0.2 \mathrm{ml}$ portions of the mixtures were analysed for $5 \mathrm{~N}$ activity with the ammonia method as described under "Procedure" (60 min. incubation time etc.).

The percentage recovery is expressed as the ratio of the $5 \mathrm{~N}$ activity of the former mixture minus the $5 \mathrm{~N}$

Tab. 3

Recoveries of adenosine added to serum

$0.37 \mu \mathrm{g}$ adenosine added correspond to a $5 \mathrm{~N}$ activity of $61.6 \mathrm{mU} / \mathrm{ml}$;

Sample no. 1 concerns a pooled serum from blood donors; sample 2 concerns a serum from a patient with pancreas-head carcinoma with obstructive jaundice (bilirubin $17 \mathrm{mg} / 100 \mathrm{ml}$ ); sample 3 shows serum from jance (bilirubin 17 mg/100 ml); sample $350 \mathrm{mU} / \mathrm{ml}$ bilirubin $8 \mathrm{mg} / 00 \mathrm{ml}$. With infectis pationts in the The blood was taken just before haemodialysis (urea resp. 219 and $130 \mathrm{mg} / 100 \mathrm{ml}$ )

Sample No. 6 was taken from a patient suffering from KAHLER disease (erythrocyte sedimentation rate $36 \mathrm{~mm}-1$ hour)

\begin{tabular}{llccc}
\hline Sample & diagnosis & $\begin{array}{c}\text { adenosine } \\
\text { added } \\
(\mu \mathrm{g})\end{array}$ & $\begin{array}{c}\text { recovery } \\
\%\end{array}$ & $\begin{array}{c}\text { standard } \\
\text { deviation } \\
(\%)\end{array}$ \\
\hline 1. & $\begin{array}{l}\text { normal } \\
\text { carcinoma of pancreas }\end{array}$ & 0.37 & 102 & \pm 2.3 \\
2. & $\begin{array}{l}\text { with obstruction } \\
\text { 3. }\end{array}$ & 0.37 & 97.3 & \pm 2.0 \\
4.patitis & 0.16 & 106.3 & \pm 2.4 \\
5. & läst stage & 0.37 & 94.8 & \pm 2.8 \\
6lomerulonephritis & idem & 0.37 & 92.8 & \pm 2.6 \\
\hline
\end{tabular}


activity of $0.2 \mathrm{ml}$ of the same serum diluted two-fold with physiological saline, and the difference calculated on the basis of the known amount of adenosine added.

\section{Discussion}

There is little information as to what extent phosphateester splitting enzymes - specific or not - contribute to serum 5'-nucleotidase elevations in hepatobiliary diseases. Strictly one should speak of serum activity towards AMP and not of serum 5'-nucleotidase, because there is only - as has been pointed out by SchwarTz and BODANSKY (5) - "a qualitative impression" about the existence of a specific $5 \mathrm{~N}$ in serum. This impression emerges from a report from Rers (18). He demonstrated that a human liver-homogenate hydrolyses AMP at $\mathrm{pH}$.7.5 more rapidly (about ten times) than phenylphosphate or other phosphoric esters, and that the converse situation occurs at $\mathrm{pH} 9.0$.

In 1958 AHMED and Rers (19) reported that at $\mathrm{pH} 7.5$ a homogenate of placental tissue splits AMP at a higher rate than phenylphosphate but that in the presence of $0.001 \mathrm{M} \mathrm{Ni++}, 1$. both substrates are split at an equal rate, and 2 . the splitting of phenylphosphate is not affected by the presence of $0.001 \mathrm{M} \mathrm{Ni++}$. These authors conclude that $\mathrm{Ni}^{++}$almost completely inhibits $5 \mathrm{~N}$ activity in placental tissue extract. Since then a number of investigations have determined serum $5 \mathrm{~N}$ activity in the presence and absence of $\mathrm{Ni}^{++}$ions. The difference in activities is assumed to represent specific $5 \mathrm{~N}$ activity $(2,6,7,20, \dot{2} 1)$. In this respect some critical remarks must be made. Firstly the equal activity with AMP and $\mathrm{PhP}$ in the presence of $\mathrm{Ni}^{++}$ions does not mean that specific $5 \mathrm{~N}$ activity is suppressed, since these esters are in general split at quite different rates by nonspecific phosphatase (22).

Secondly the activity of serum does not seem comparable with that of placental extract, since $\mathrm{Mg}^{++}$strongly activates $5 \mathrm{~N}$ in serum (fig. 1) while it does not do this in placenta (19). Thirdly $\mathrm{Ni}^{++}$inhibits to a great extent human bone phosphatase (21). Thus the question remains which serum enzymes - and to what extent do in fact remain active in the presence of $\mathrm{Ni}^{++}$. Therefore we have not included additions of $\mathrm{Ni}^{++}$in the standard procedure. It should be pointed however that we found that $\mathrm{ADA}$ remains fully active in the presence of $0.001 \mathrm{M} \mathrm{Ni} \mathrm{Ni}^{++}$. This means that with the new method presented here activities with AMP can also be measured in the presence of $\mathrm{Ni}^{++}$. Young (2) corrected for nonspecific phosphatase by preincubating serum with $0.0015 \mathrm{M}$ EDTA which should inactivate more AP than $5 \mathrm{~N}$, and Kowlessar and coworkers (1) estimate $5 \mathrm{~N}$ in the presence of high concentration of $\mathrm{Mg}^{++}$which would inhibit alkaline phosphatase completely. Any proof for these conditions of inactivation is lacking in their reports.

Dixon and Purdon (4) estimated the alkaline phosphatase contribution to the hydrolysis of AMP by measuring the hydrolysis of phenyl phosphate at $\mathrm{pH}$ 7.5. By subtracting the latter activity from the activity with
AMP the specific $5 \mathrm{~N}$ activity was determined. The disadvantage of this correction lies in the fact that the splitting of phenyl phosphate by alkaline phosphatase is higher than that of AMP, resulting therefore in excessively high subtractions.

It is interesting to note that generally in nonclinical biochemistry $5 \mathrm{~N}$ estimations are not corrected for interference by alkaline phosphatase even if they are performed at $\mathrm{pH}$ 8.5. For clinical purposes the only correction to be made in our opinion is a correction for the residual acitvity of bone phosphatase with AMP at $\mathrm{pH}$ 7.5. SCHWARTZ and BODANSKY (21) have reported that this residual activity is only $3 \%$ of the activity at $\mathrm{pH} 9.1$ with $\beta$-glycerophosphate. The test conditions for realizing such corrections in individual serum determinations are not known at present.

All investigators, including BADAwill and Chang (3), who do not apply a correction for alkaline phosphatase interference in $5 \mathrm{~N}$ estimations, agree that serum $5 \mathrm{~N}$ estimations are valuable in the differentiation of elevated serum phosphatase due to liver or bone diseases: in liver disease usually the $5 \mathrm{~N}$ value is increased, while it is not in the case of bone disease associated with enhanced osteoblastic activity. These findings fit into the observations of Young (2) that the serum $5 \mathrm{~N}$ levels of normal growing children are in the adult range but that their alkaline phosphatase levels are higher than in the adult range. In our experience they also fit with the fact that sera showing a typical bone or osteoblast fraction in their electrophoretic isoenzyme pattern have normal $5 \mathrm{~N}$ levels (uncorrected) and elevated alkaline phosphatase. The number of these serums (seven) is too small for statistic evaluation. The matter merits further investigation, since the present method is more sensitive and accurate than the method based on phosphate determinations. The accuracy can be illustrated for example by figure 3, table 2 and 3 and the fact that the transition from normal to elevated levels corresponds to extinction values (1 $\mathrm{cm}$ cells) of approx. 0.140 (phosphate methods $\pm 0.040)$. It offers the opportunity to carry out inactivation experiments, since we found out that $\mathrm{ADA}$ remains fully active in the presence of $0.017 \mathrm{M}$ EDTA, $0.001 \mathrm{M} \mathrm{Ni} \mathrm{N}^{++}$or $0.080 \mathrm{M} \mathrm{KCN}$. Further advantages of the present method are: most of the reagents are quite stable, and a minimum of pipettings is required, since the necessity of deproteinisation is avoided and the substrate and ADA are added in one combination. Interference by pathological serums, introducing errors in the determination, have not been observed.

Note added to proof

Some commercial batches of AMP or ADA have been found to be contaminated with free adenosine and active AMP-deaminase respectively.

In such cases for each series of tests for $5 \mathrm{~N}$ the following control must be done: a tube containing $1 \mathrm{~m} /$ buffer/substrate/ADA is incubated for $60 \mathrm{~min}$. at $37^{\circ} \mathrm{C}$ after which the reagents for ammonia are added as described in the standard Procedure. Absorbance ( $A_{\text {corr. }}$ ) is read at $625 \mathrm{~nm}$ against a blank from which the substrate has been omitted. From all measured values of $A_{x}$ this amount of $\mathrm{A}_{\text {corr. }}$ has to be subtracted. 


\title{
References
}

1. Kowlessar, O. D., L. J. Haeffiner, E. M. Riley and M. H. Sleisenger, Amer. J. Med. 31, 231 (1961). - 2. Young, I. I., Ann. N. Y. Acad. Sc. 75, 357 (1958). - 3. Bardawill, C and C. Chang, Canad. Med. Ass. J. 89, 755 (1963). - 4. Dixon, I. F. and M. Purdon, J. Clin. Path. (London) 7, 341 (1954). - 5. Schivartz, M. K. and O. Bodansky, Cancer 18, 886 (1965). 6. Camprelel, D. M., Bioch. J. 82, 34 P.(1962). - 7. Frenkel, M. and A. J. van TrIET, Israel Med. J. 23, 18 (1964). - 8. FISKE, C. H. and Y. Subbarow, J. biol. Chemistry 66, 375 (1925). - 9. Kalckar, H. M., J. biol. Chemistry 167, 445 (1947). - 10. Segar, H. L. and B. M. Brenner, J. biol. Chemistry 235, 471 (1960). 11. Heppel, L. A. and R. J. Hilmoe, J. biol. Chemistry 188, 665 (1951). - 12. Chilson, O. P. and J. R. Fisher, Arch. Biochem.
Biophysics 102, 77 (1963). - 13. BraDY, T., Biochem. J. 36, 478 (1942). - 14. Berthelot, M. P. E., Rép. Chim. appl. 1, 282 (1859). - 15. Chaney, A. L. and E. P. Marbach, Clin. Chem. (New York) 8, 130 (1962). - 16. Martinek, R. G., Clin. Chem. (New York) 9, 620 (1963). - 17. Henry, R. J. and R. L. Dryer, in Standard Methods of Clinical Chemistry, D. Seligson, Ed. vol 4, 217 (1963) Academic Press. N. York. - 18. Rers, J. L., Biochem. J. 48, 548 (1951). - 19. Armed, Z. and J. L. Rers, Biochem. J. 69, 386 (1958). - 20. Hirl, P. G. and H. G. Sammonds, Clin. Chim. Acta (Amsterdam) 13, 739 (1966). - 21. Schwartz, M. K. and O. Bodansky, Amer. J. Clin. Path. 42, 572 (1964). - 22. KInG, E. J. and G. E. Delory, Biochem. J. 33, 1185 (1939).

Dr. J.-P. Persijn

Antoni van Leeuwenhoekhuis Sarphatistraat 108

Amsterdam

\section{Immunochemical Quantitation of Serum $\beta_{1 \mathrm{~A}}$-Globulin in Health and Disease}

\author{
By A. Agostoni, C. Vergani and R. Stabilini \\ From Istituto di Semeiotica Medica, University of Milan, Italy
}

(Eingegangen am 9. Mai 1968)

The $\beta_{1 \mathrm{~A}}$ globulin concentration was quantitatively determined in the sera of healthy subjects of different age and sex, as well as in the sera of patients with various diseases, using single radial immunodiffusion on cellulose acetate strips.

Very low levels were found in the cord blood, but a singificant increase was observed during the first days of life. Lower values were found in women if compared with men or children.

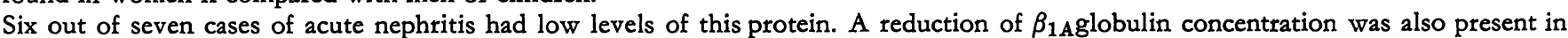
sera of patients with liver cirrhosis (7 out of 14 cases).

Unter Anwendung der radialen Immundiffusion auf Celluloseacetat wurde die Konzentration des $\beta_{1 \mathrm{~A}}$ Globulins im Serum von Normalpersonen verschiedenen Alters und beiderlei Geschlechts und Patienten mit diversen Krankheitsformen quantitativ untersucht. Die Konzentration dieses Proteins war sehr niedrig im Nabelschnurblut, aber schon in den ersten Lebenstagen signifikant erhöht. Frauen zeigten tiefere Werte als Kinder und Männer. Die Konzentration. dieses Proteins war im Laufe von akuter Nephritis und in 7 von 14 Leberzirrhosefällen erniedrigt.

Since a drop in serum concentration of the complement component $\mathrm{C}_{3 \mathrm{~A}}\left(\beta_{1 \mathrm{C}}-\beta_{1 \mathrm{~A}}\right.$ globulin) has been found to occur in children with glomerulonephritis, much interest has emerged in studies on this protein $(1-5)$. However, the concentration of $\beta_{1 \mathrm{~A}}$ globulin has been determined semiquantitatively: quantitative data have been presented only recently by SANDOR and Coworkers (6).

The present investigation was undertaken to study the influence of age and sex on the serum content of $\beta_{1 \mathrm{~A}}$ globulin in normal subjects, and its modifications in pathological states.

\section{Material and Method}

The concentration of $\beta_{1 \mathrm{~A}}$ globulin was determined in 218 subjects. To avoid the presence of antigens with different molecular weights, the sera were studied only after the $\beta_{1}$ cglobulin had been completely converted in to $\beta_{1 \mathrm{~A}}$ globulin (i. e. by incubation at $37^{\circ} \mathrm{C}$ for 3 days) (Fig. 1).

Quantitative determinations were carried out by single radial immunodiffusion on cellulose acetate. The method has been described elsewhere (7). The specific anti- $\beta_{1} c / \beta_{1 A}$ antiserum

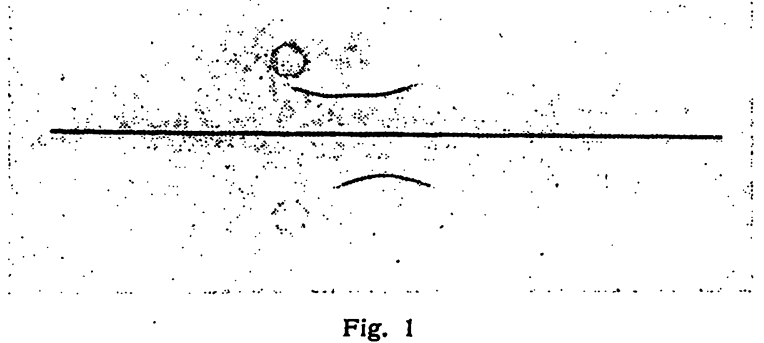

Immunoelectrophoresis of healthy human serum with anti- $\beta_{1 \mathrm{~A}} / \boldsymbol{\beta}_{1 \mathrm{C}}$ rabbit antiserum (above $=$ native serum; below $=$ after 3 days at $37^{\circ} \mathrm{C}$ ). The fresh serum shows a double arc corresponding to the $\beta_{1 \mathrm{C}}$ and $\beta_{1 \mathrm{~A}}$ globulins; the aged serum shows the single $\beta_{1 \mathrm{~A}}$ arc

(Behringwerke, Marburg/Lahn, Germany) was diluted 1:10. Strips of cellulose acetate $3.9 \times 31.5 \mathrm{~cm}$ (Schleicher \& Schüll, Dassel Germany) were used: 50 sample determinations can be carried out on each strip (Fig. 2). The linear relation existing

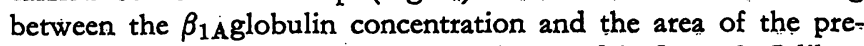
cipitate at the end of the diffusion is illustrated in figure 3. Calibration curves were obtained using a standard human serum with a known concentration of $\beta_{1 \mathrm{Aglobulin}}$ (Standard Human Serum, Behringwerke Op. Nr. 166). 